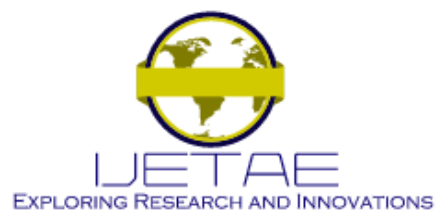

International Journal of Emerging Technology and Advanced Engineering

Website: www.ijetae.com (ISSN 2250-2459, ISO 9001:2008 Certified Journal, Volume 4, Issue 3, March 2014)

\title{
MPPT Controlled VSI Based Grid Connected Hybrid Energy Conversion System
}

\author{
T.Shanthi ${ }^{1}$, Navis Rashmi. ${ }^{2}$ \\ ${ }^{1}$ Professor, ${ }^{2}$ PG Scholar, Dept. of EEE, Kumaraguru College of Technology, Coimbatore, India-641049
}

\begin{abstract}
This Paper describes the grid connected hybrid renewable energy system. The hybrid wind energy conversion system (WECS)/photovoltaic (PV) and fuel cell (FC) system is an excellent option for distributed energy production. Input sources such as wind and photovoltaic are primary power system and fuel cell as a secondary power system. The objective of this paper is aimed at controlling the hybrid system that guarantees the energy continuity. During sudden change in load condition bidirectional support is offered by aptly controlling the inverter. A novel MPPT controller is also established at the inverter side. A Voltage source inverter employing current control is used to connect the proposed system to the grid to achieve stabilization if one or more of the energy sources are diminished. The entire proposed system has been modeled and simulated using MATLAB/Simulink software.
\end{abstract}

Keywords- Fuel cell (FC), Solar Photovoltaic (PV), Maximum power point tracking (MPPT) controller, Voltage source inverter, Wind energy conversion system (WECS).

\section{INTRODUCTION}

The recent increase in energy consumption on a drastic level has affected the developments in Renewable energy technology for the betterment of mankind. Widely used renewable energy sources are wind power, solar power, geothermal power, bio power etc . Out of these Wind and solar power are readily available and cost effective. Combining these two highly advantageous systems will invariably offer a huge advantage in terms of supplementing increased levels of power demand. This project aimed at developing the previously mentioned idea also including fuel cell technology to create a self sustaining hybrid energy conversion system that is directly connected to the grid. The main objectives include supplying uninterrupted power for various ranges of load using fuel cell as a backup source and solar and wind as the primary source. Photovoltaic (PV) power is global and it can be extracted without using rotational generators.

Hence, to get an uninterrupted supply wind-PV hybrid power generation system [1] [2] can be implemented.
The wind energy conversion system consists of wind turbine, induction generator. The ac output from WECS is converted into dc by three phase diode rectifier. Solar panel is connected to the grid via boost converter it is designed in such a way that it equalizes the solar power derived with the wind power[3].Fuel cell is connected to the bidirectional converter which operates on a reference power taken from MPPT controlled voltage source inverter[4][5].The three-phase voltage fed PWM inverter is connected to the power grid and the loads through the three phase transformer[wind]. The VSI inverter provides a power conversion from the $\mathrm{dc}$ bus to the grid and controls the grid at unity power factor. The inverter performs the control of dc bus voltage at the input of the inverter.

The paper is organized as follows. The overall architecture of the MPPT controlled VSI based grid connected[6][7] hybrid energy system and the description of the system are described in section II and section III respectively. and the simulation results of the proposed system are included in section IV.

\section{PRoposed Scheme}

Fig.1. illustrates the overall architecture of the proposed system with wind, PV and Fuel cell sources. Through individual converters all three energy sources are connected in parallel to a common DC bus. The three different outputs from the power sources are integrated on the dc side and parallely combined using a voltage source inverter to provide the desired power to the grid and grid connected loads even if the primary power sources cannot meet the power demand.

The VSI allows the integration of the wind and PV energy resources along with fuel cell and as mentioned earlier this type of inverter is more effective with maximum power point tracking (MPPT). This proposed system uses sine pulse width modulation method to generate gating pulses that enable to drive the controllable switches of the VSI along with eminent usage of proportional integral controller (PI controller). 


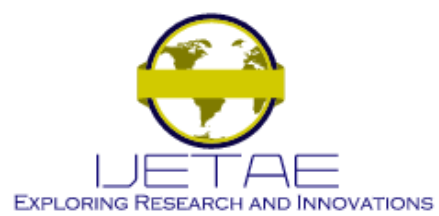

\section{International Journal of Emerging Technology and Advanced Engineering}

Website: www.ijetae.com (ISSN 2250-2459, ISO 9001:2008 Certified Journal, Volume 4, Issue 3, March 2014)

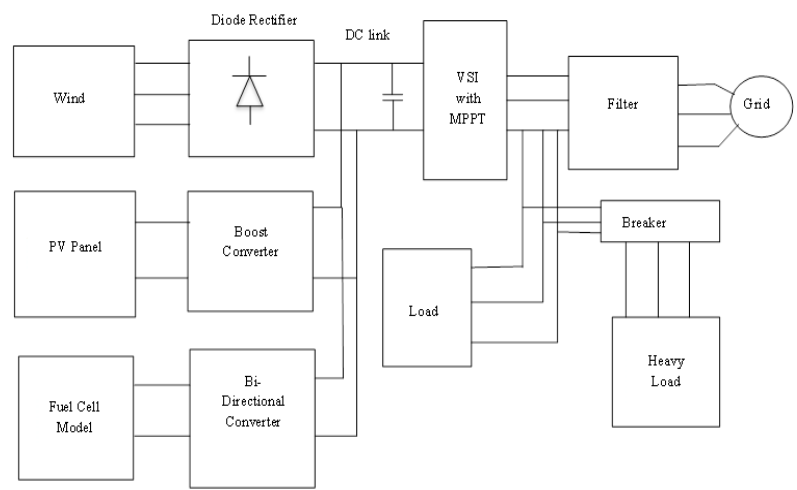

Fig.1. Overall architecture of the proposed system

The PV voltage is adjusted by appropriate switching of the boost converter to maximize the average power output of the array. At a given irradiation condition, the working voltage of the PV array is varied and therefore, the power flow from the PV varies. For a given level of solar irradiance, inspection of the PV array characteristic reveals that the point of maximum power is approximately achieved with an output voltage Vmp which is proportional to the open-circuit voltage Voc of the PV array.

\section{SYSTEM DESCRIPTION}

\section{A. Wind Energy Conversion System:}

This paper uses a wind model present in the MATLAB/Simulink library. The WECS contains wind turbine and permanent magnet synchronous generator. The permanent magnet synchronous generator converts mechanical output $(\mathrm{Tm})$ of the wind turbine into electrical output. Hence the output of the wind model is three phase ac voltage. It is converted into DC by three phase diode rectifier.

The inputs to the wind turbine are pitch angle $(\beta)$, rotor speed and wind speed ( $\mathrm{V}$ wind) of the permanent magnet synchronous generator.

The fundamental equation governing the mechanical power capture of the wind turbine rotor blades, which drives the electrical PM generator, is given as,

$$
P=1 / 2 \rho A C p V^{3}
$$

Where the air density $(\mathrm{kg} / \mathrm{m} 3)$ is $\rho$, the area swept by the rotor blades is A,the air velocity $(\mathrm{m} / \mathrm{s})$ is $\mathrm{V}$, the power co efficient of the wind turbine is $\mathrm{Cp}$.

The wind turbine is characterized by its Cp-TSR characteristic, where the Tip speed ratio is given by

$$
T S R=\omega m R / V
$$

The mechanical angular speed and the turbine radius are $\omega \mathrm{m}$ and $\mathrm{R}$ respectively and $\mathrm{V}$ is the wind speed. The power coefficient has its maximum value at the optimal value of the tip-speed ratio which results in optimum efficiency of the wind turbine and capture of maximum available wind power by the turbine.

\section{B. Photovoltaic System:}

A PV cell can be represented by equivalent circuit shown in Fig. 2.The characteristics of this PV cell can be obtained using standard equation.

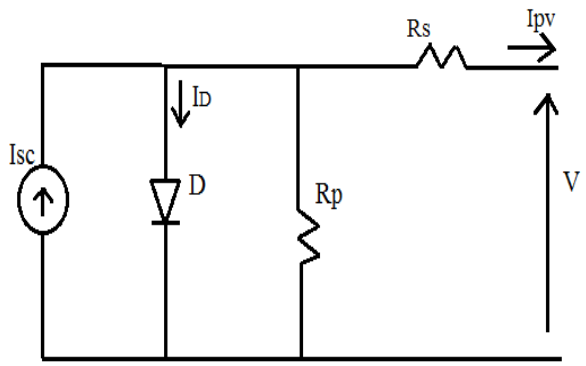

Fig .2.Single diode model of solar cell with Rs and Rf

$I p v=N p I s c-N s I o\left\{\exp \left(\frac{q(V p v+I p v R s)}{N s A K T}\right)-1\right\}-V p v+$ $\left(\frac{I p v R s}{R p}\right)$

Ipv - Photovoltaic current

Io -Saturation Current

Ns - No of cells connected in series

$\mathrm{Np}$ - No of cells connected in parallel

$\mathrm{T}$-Temperature of $\mathrm{p}-\mathrm{n}$ junction

K-Boltzmann constant

q-Electron charge

Rs-equivalent series resistance of the array

$\mathrm{Rp}$-equivalent parallel resistance of the array.

A-diode ideality factor

The PV panel is connected to a dc-dc boost converter that provides a stepped-up voltage to the dc-bus link. The PV voltage is adjusted by appropriate switching of the boost converter to maximize the average power output of the array. At a given irradiation condition, the working voltage of the PV array is varied and therefore, the power flow from the PV varies. The boost converter is then connected to the inverter via DC link.

\section{Fuel Cell System:}

Fuel cell is an electrochemical device. It converts the chemical potential of the hydrogen into electric power and hence it attains consequent high conversion efficiency. 


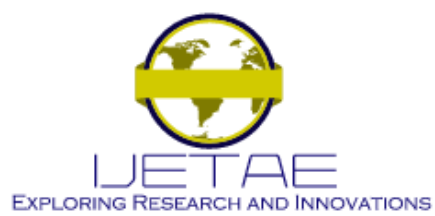

\section{International Journal of Emerging Technology and Advanced Engineering}

Website: www.ijetae.com (ISSN 2250-2459, ISO 9001:2008 Certified Journal, Volume 4, Issue 3, March 2014)

During the load varying conditions the fuel cell is utilized as the auxiliary power source for smoothing the output power demand. Hence the fuel cell is connected to the bidirectional DC-DC converter and then to the DC link which works in rectification as well as inversion mode. The inverter power along with the WEC and PV systems output is fed back to the fuel cell for the power control.

\section{Voltage Source Inverter With Mppt Control:}

Output voltage from an inverter can also be adjusted by controlling the inverter from within itself. The most efficient method of doing this is by mppt control used within an inverter which is switched using sinusoidal pulse width modulation technique[9][10]. The MPPT control for the VSI is done by measuring the current from the grid side $i_{s d}$ and $d c$ bus voltage $V_{d c}$. From this data $i_{s d}^{*}$ which is current reference is calculated and fed to the current controller along with $I_{d}$ and $I_{q}$ which is obtained by applying transformation on 3 phase inverter output current.

$$
i_{s d}^{*}=\frac{K_{o p t}}{V_{s}} f^{3}
$$

Where $K_{\text {opt }}$ is a constant based on the wind turbine. $K_{\text {opt }}$ is given by

$$
K_{\text {opt }}=\frac{1}{2} \rho \pi R^{2} C_{\text {opt }} \eta_{g} \eta_{b}\left(\frac{2 \pi R}{p \lambda_{\text {opt }}}\right)^{3}
$$

Where $C_{o p t}$ is the maximum power coefficient, $\lambda_{o p t}$ is the optimum tip speed ratio, $\rho$ is the air density (in kilograms per cubic meter), $\mathrm{R}$ is the turbine radius , $\eta_{g}$ is the generator efficiency, $\eta_{b}$ is the gearbox/bearings efficiency and $p$ is the number of pair poles of the generator.

From the transformation's output voltages magnitude and angle are input to the sine wave generator which compares the carrier signal fed along with the reference sine wave and thus gating signals to the inverter are produced.

The current reference isd* of the grid side inverter is calculated from the maximum output power ie) vdc is the measured dc link voltage and isd is the measured active current of the inverter.

In VSI inverter MPPT controller and spwm technique is used to generate proper pulses for driving the controllable switches of the inverter.

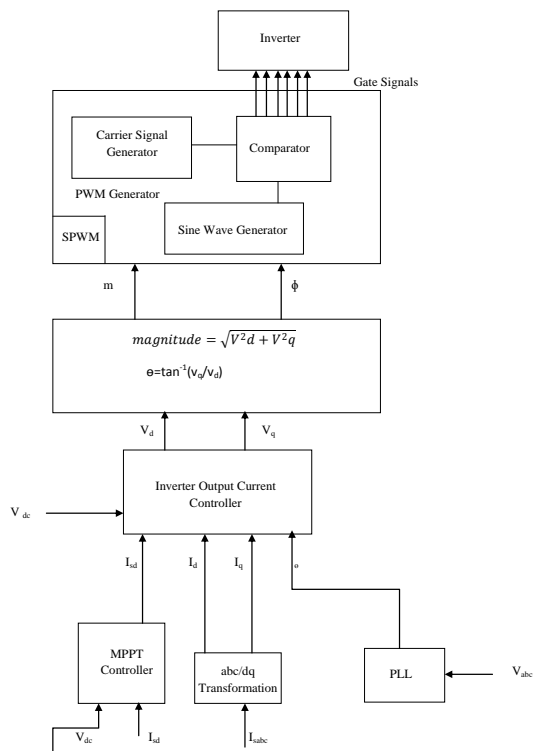

Figure .3 Overall scheme of MPPT controlled VSI .

IV. MATLAB SIMULINK MODELLING AND SIMULATION RESULTS

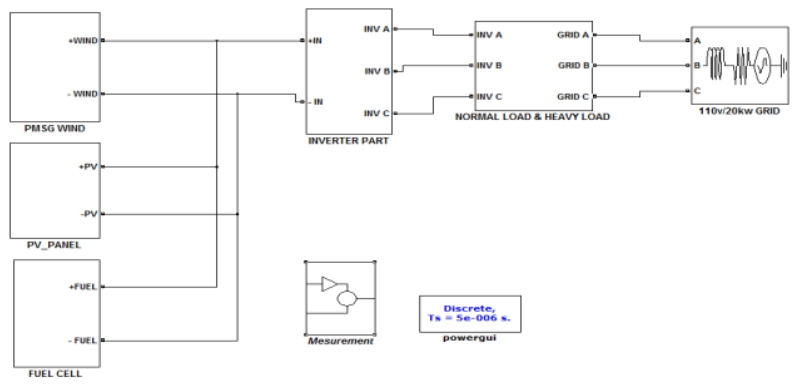

Fig.5 MATLAB model of MPPT Controlled VSI Based Grid Connected Hybrid Energy Conversion System

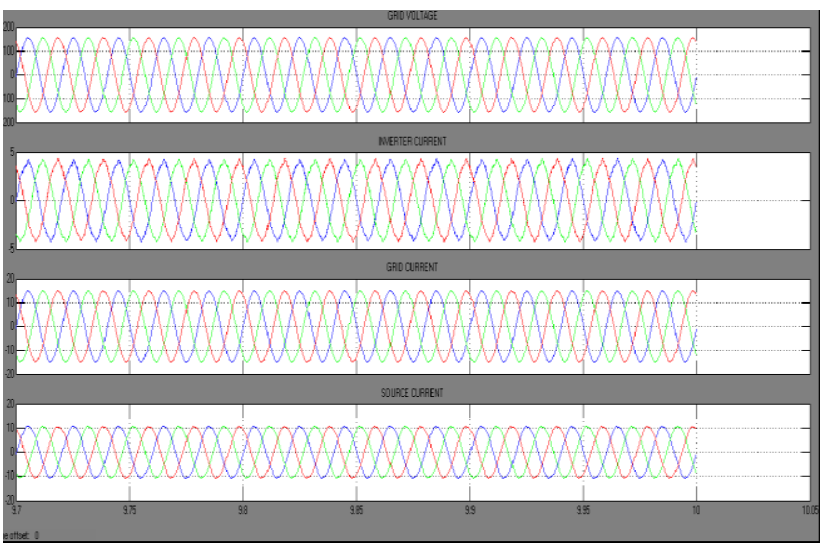

Fig .6 Generated grid voltage, grid current,inverter current and source current. 


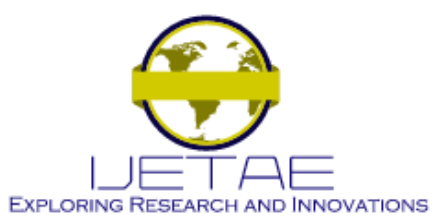

\section{International Journal of Emerging Technology and Advanced Engineering}

Website: www.ijetae.com (ISSN 2250-2459, ISO 9001:2008 Certified Journal, Volume 4, Issue 3, March 2014)

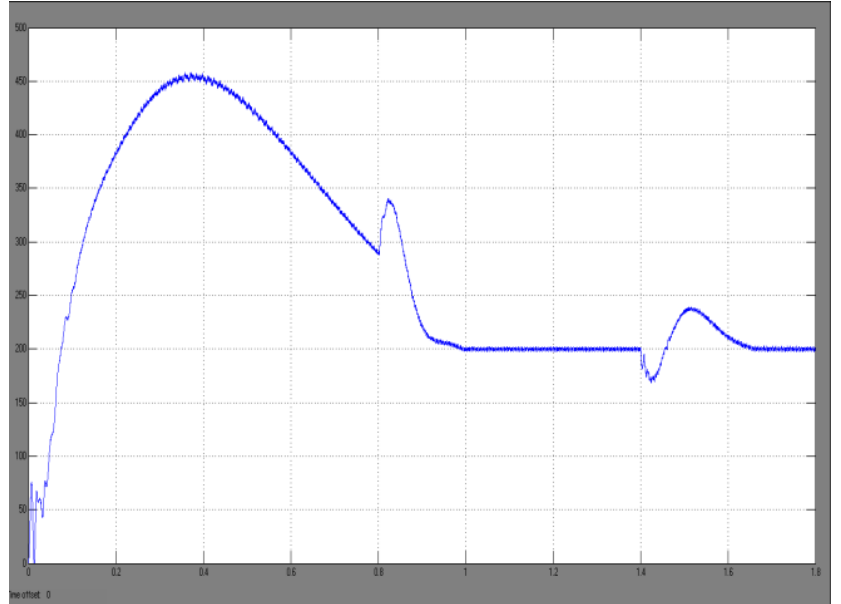

Fig.7 Generated DCbus voltage across the hybrid energy sources

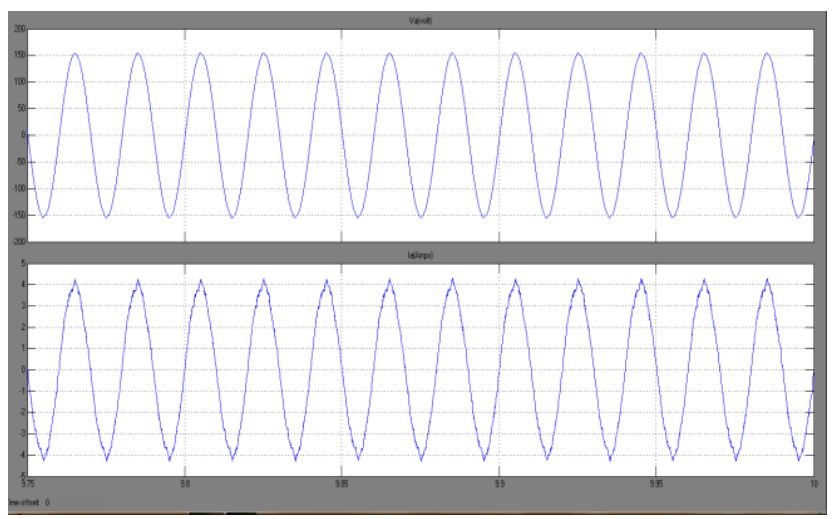

Fig .8 waveform showing unity power factor operation

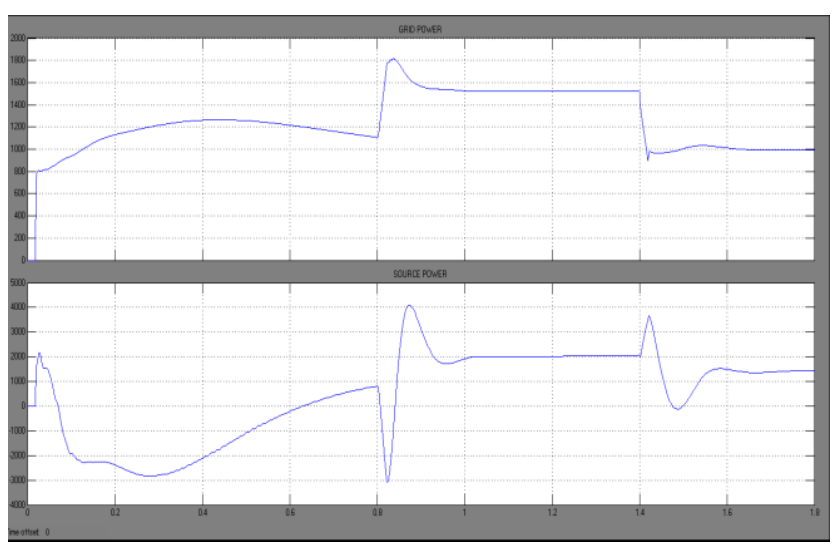

Fig.9 waveform showing inverter power and grid power for varying loads.

The proposed simulation results carried out using MATLAB r2009 Simulink software.
Fig.4 shows the simulation model hybrid energy system employing wind,solar and fuel cell system with voltage source inverter using MPPT controller.The output voltage obtained from the three different sources attains a constant $200 \mathrm{v} \mathrm{dc}$ voltage which is connected to the inverter so that it balances the variations in load levels.By operating at unity power factor and by monitoring active and reactive power levels the overall system performance can be maintained at high levels.

\section{CONCLUSION}

This paper presents a hybrid energy system working with mppt controlled VSI .The proposed hybrid system is able to provide almost continuous electric power across the grid thus supplies the load demand with better reliability than a single power source.The inverter power factor is maintained at unity. Thus by using a combination of renewable energy sources with the fuel cell as a backup demands on the load side is supplied even when it is varying drastically.

\section{REFERENCES}

[1] Abdullah M.A, Yatim A.H.M, Tan C.W, Saidur R, A review of maximum power point tracking algorithms for wind energy systems. Renewable and Sustainable Energy Reviews vol.16,pp.3220-3227, 2012.

[2] N.A. Ahmed, M. Miyatake, A.K. Al-Othman, Power fluctuations suppression of stand-alone hybrid generation combining solar photovoltaic/wind turbine and fuel cell systems, Energy Convers. Manage. vol.49 No. 10 2711-2719, 2008.

[3] Y. Chen and K. M. Smedley, "A cost-effective single-stage inverter with maximum power point tracking," IEEE Trans. Power Electron., vol. 19, no. 5, pp. 1289-1294, Sep. 2004.

[4] Katsumi Nishida, Tarek Ahmed and Mutsuo Nakaoka," A Cost-Effective High-Efficiency Power Conditioner With Simple MPPT Control Algorithm for Wind-Power Grid Integration",IEEE Trans on Industry Applications, vol. 47, no. 2, 2011.

[5] G. R.Walker and P. C. Senia, "Cascaded DC-DC converter connection of photovoltaic modules," IEEE Trans. Power Electron., vol. 19, no. 4,pp. 1130-1139, Jul. 2004.

[6] B. M. T. Ho and S.-H. Cheng, "An integrated inverter with maximum power tracking for grid-connected PV systems," IEEE Trans. Power Electron., vol. 20, no. 4, pp. 953-962, Jul. 2005.

[7] W. Liu, J. Chen, T. Liang, R. Lin and C. Liu, "Analysis, design, and control of bidirectional cascaded configuration for a fuel cell hybrid power system," IEEE Trans. Power Electron., vol.25, no.6, pp.1565-1575, June 2010.

[8] J. Bauman and M. Kazerani, "A comparative study of fuel-cell-battery, fuel-cell-ultra capacitor, and fuel-cell-battery-ultra capacitor vehicles," IEEE Trans. Veh. Technol., vol.57, no.2, pp.760-769, 2008.

[9] T. Ahmed, K. Nishida, and M. Nakaoka, "Advanced control of PWM converter with variable speed induction generator," IEEE Trans. Ind. Appl.,vol. 42, no. 4, pp. 934-945, Jul./Aug. 2006. 


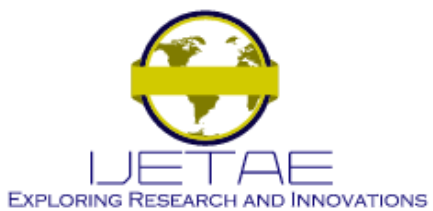

International Journal of Emerging Technology and Advanced Engineering Website: www.ijetae.com (ISSN 2250-2459, ISO 9001:2008 Certified Journal, Volume 4, Issue 3, March 2014)

[10] R. Pena, J. C. Clare, and G. M. Asher, "Doubly fed induction generator using back-to-back PWM converters and its application to variable-speed wind-energy generation," Proc. Inst. Elect. Eng.-Elect. Power Appl.,vol. 143, no. 3, pp. 231-241, Feb. 1996.

\section{AUTHORS DETAILS:}

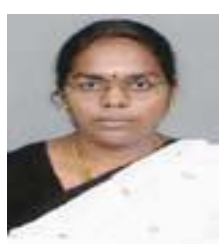

T. Shanthi received her bachelor's degree from Institute of Road and Transport Technology, Erode, Tamilnadu, India in Electrical and Electronics Engineering during 1999. She received her Master's degree from National Institue of Technology, Tiruchirappalli, India during 2007. She is currently working as Assistant Professor at the department of Electrical and Electronics Engineering in Kumaraguru College of Technology, Coimbatore, India. Her areas of interest are Renewable energy sources, Power electronic applications for solar and wind energy and intelligent control techniques for power system.

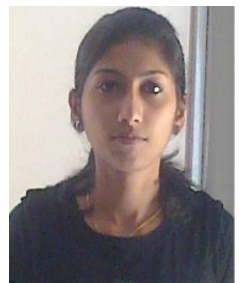

A. Navis Rashmi was born in Kanya Kumari, Tamil- Nadu, India, on April, 1991. She received the B.E. degree from Jeppiaar Engineering College, Chennai (Anna University, Chennai, India) in 2012. She is undergoing her M.E. degree in Kumaraguru college of Technology, Coimbatore. Her area of interests include Power System and renewable energy sources. 